\title{
Effects of Carbon Dioxide Treatment and Modified Atmosphere Packaging on the Quality of Long Distance Transporting “Maehyang” Strawberry
}

\author{
Hyun Jin Choi, Yeong Seuk Bae, Jung Soo Lee, Me Hea Park, Ji Gang Kim
}

Postharvest Technology Division, National Institute of Horticultural and Herbal Science, Rural Development Administration, Wanju, Republic of Korea

Email: chyunjin@korea.kr

How to cite this paper: Choi, H.J., Bae, Y.S., Lee, J.S., Park, M.H. and Kim, J.G. (2016) Effects of Carbon Dioxide Treatment and Modified Atmosphere Packaging on the Quality of Long Distance Transporting "Maehyang" Strawberry. Agricultural Sciences, 7, 813-821.

http://dx.doi.org/10.4236/as.2016.712074

Received: October 31, 2016

Accepted: November 25, 2016

Published: November 28, 2016

Copyright $\odot 2016$ by authors and Scientific Research Publishing Inc. This work is licensed under the Creative Commons Attribution International License (CC BY 4.0).

http://creativecommons.org/licenses/by/4.0/

(c) (i) Open Access

\begin{abstract}
This study was conducted to investigate the effects of carbon dioxide $\left(\mathrm{CO}_{2}\right)$ and modified atmosphere (MA) packaging on the quality of strawberry during long distance transportation. "Maehyang" strawberries (Fragaria x ananassa Duch.) with red color on $70 \%$ of the fruit surface were harvested in Gyeongnam province, Korea. The samples were placed in gas-tight chamber with $30 \% \mathrm{CO}_{2}$ concentration for 3 hours at $3^{\circ} \mathrm{C}$. Strawberry samples were then packaged with modified atmosphere-modified humidity $(\mathrm{MA} / \mathrm{MH})$ packaging film. Samples treated with $\mathrm{CO}_{2}$ alone and combined $\mathrm{CO}_{2}$ with MA packaging were stored for one day at $1^{\circ} \mathrm{C}$, transported for 10 days at $1^{\circ} \mathrm{C}$, and distributed for 3 days at $4^{\circ} \mathrm{C}$. Carbon dioxide alone or combination with MA packaging was effective in maintaining quality of "Maehyang" strawberries. Carbon dioxide treatment significantly increased firmness and reduced softening index and decay rate during 14 day transportation and distribution. Samples treated with $\mathrm{CO}_{2}+\mathrm{MA}$ had higher overall score with low softening index and weight loss after 14 days of transportation and low temperature distribution compared to $\mathrm{CO}_{2}$ treatment only. The results indicated that a short term application of $\mathrm{CO}_{2}$ or combination treatment of $\mathrm{CO}_{2}$ and $\mathrm{MA}$ could be good postharvest handling for maintaining freshness of "Maehyang" strawberries during long distance vessel export.
\end{abstract}

\section{Keywords}

Carbon Dioxide, Firmness, Modified Atmosphere, Quality, Strawberry

\section{Introduction}

Strawberry is highly perishable fruit and requires careful handling in order to maintain quality after harvest. Strawberry is considered as winter fruit in Korea because con- 
sumption of the fruit is high in winter season. Though the domestic market of strawberry has been increased in Korea, the strawberry industry tries to expand the export market. Total strawberry export has been increasing and the trend is expected to remain strong, mainly due to the increased shipments to South East Asian countries such as Singapore and Hong Kong of China [1]. However, strawberry has a limited shelf-life due to rapid softening and decay during postharvest handling such as transportation, storage and marketing. The main characteristics related to the market quality of strawberry fruits are texture (firmness), flavor and decay rate. Generally, fungal decay is caused to loss of quality on strawberry for storage time [2]. It is therefore important to apply an appropriate postharvest treatment to delay respiration, prevent physical damage, dryness and to restrict fungal decay in order to extend shelf-life. Postharvest treatment such as precooling [3], storage at low temperature [4], carbon dioxide [2] [5] [6] and chlorine dioxide [7] can be used for this purpose. For example, Lee H.J. et al. reported that a short term application of $\mathrm{CO}_{2}$ during cooling has a benefit for keeping freshness of strawberries during export and local marketing [5]. Harker F.R. et al. reported that mechanism for $\mathrm{CO}_{2}$-induced firmness enhancement in strawberry is due to changes in the $\mathrm{pH}$ of the apoplast. Such changes in $\mathrm{pH}$ may promote the precipitation of soluble pectins and thus enhance cell-to-cell bonding in strawberry fruit [6].

Controlled atmosphere or modified atmosphere (CA or MA) has been used successfully on maintaining the quality of strawberries. Modified atmosphere packaging can be considered as a self-contained form of controlled atmosphere designed to maintain the internal gas composition of the packaging during transportation and storage. A modified atmosphere extends the shelf-life of the fruits, whereas the sealed container protects them from exposure to diseases and other environmental contaminants [8]. Controlling the relative humidity and storage temperature were important factors for keeping the freshness of fruits.

To increase the export of fruit, such as strawberries, it is necessary to develop the postharvest management of fruit during retail marketing after transportation. Compared to air transportation, vessel export is cheaper and can move higher volumes, but it takes 3 - 10 days longer to transport goods. Vessel export would seem unsuitable for strawberries, a fruit that can over ripen easily and become soft or rot [7]. In this study, to extend the shelf-life of strawberry, we examined the $\mathrm{CO}_{2}$ treatment alone and combined $\mathrm{CO}_{2}$ with MA. We investigate the quality of "Maehyang" strawberry during different storage conditions in the retail marketing after vessel export.

\section{Material and Methods}

\subsection{Plant Materials and Treatment}

Fresh "Maehyang" strawberry fruits were grown and harvested from commercial greenhouses in Jinju, Gyeongsangnam-do, Korea. Strawberry fruits were harvested in the early morning and immediately precooled in storage room at $1^{\circ} \mathrm{C}$ for 2 hour. Fruits of uniform medium size with red color on $70 \%$ of the fruit surface were used for this study. Postharvest treatment was $30 \%$ concentration of carbon dioxide gas with 3 hour 
and using strawberry modified atmosphere packaging film (Xtend, Stepac, Israel).

\subsection{Storage, Transportation and Retail Marketing Conditions}

"Maehyang" samples treated with $30 \%$ concentration of $\mathrm{CO}_{2}$ alone and combined $\mathrm{CO}_{2}$ with MA packaging were stored for one day at $1^{\circ} \mathrm{C}$, transported for 10 days at $1^{\circ} \mathrm{C}$ by vessel container, and distribution condition; cold storage for 3 days at $4^{\circ} \mathrm{C}$, retail market $\left(10^{\circ} \mathrm{C}-15^{\circ} \mathrm{C}\right)$ and room temperature.

\subsection{Quality Evaluations}

Quality evaluations included weight loss, firmness, total soluble solid (TSS) and sensory analysis.

Weight loss was evaluated by measuring the weight of eight randomly chosen boxes. Fruits were weighed using a digital balance scale (HH320, OHAUS, NJ, USA) just before treatment in South Korea, again upon their arrival in Singapore and retail marketing duration.

All texture measurements were undertaken potable firmness testing machine (FHM-5, Takemura, Japan) and 10 individual fruit per treatment were selected for each of them.

Total soluble solids (TSS) were measured according to the AOAC procedures [9]. On each evaluation day, 5 fruit from each replicate was wrapped with 2 layer of cotton cloth and squeezed with a hand pressed juice maker. TSS of the resultant juice was measured in terms of brix using a refractometer (PAL-1, Atago Co. Ltd, Tokyo, Japan).

The sensory analysis of strawberry sample was carried out by expert panel. The member of the panel were trained to recognize and overall visual quality of strawberry sample prior to the test. These sensory qualities were evaluated by using 9-point scale (9 = excellent, 7 = good, $5=$ moderate, $3=$ poor, and $1=$ unusable). A score of 6 was considered as the limit of marketability. To incidence of decay was analyzed by eye and then quantified as a percentage by counting the number of decayed fruits divided by the total number of fruits in a single plastic box, and multiplying by 100. There were $20-24$ strawberries in each plastic box weighing approximately $280 \mathrm{~g}$. Softening score of individual fruit in a box was carried out on 5 -scale $(0=0 \%$ surface softened, $1=$ up to $10 \%$ surface softened, $2=10$ to $25 \%$ surface softened, $3=25$ to $50 \%$ surface softened, and 4 $=>50 \%$ surface softened) $[2]$.

\subsection{Statistical Analysis}

The experiment was conducted with three replications per treatment. Statistical analyses of the data were carried out using SAS software (SAS Institute, Cary, NC, USA). The level of significance was calculated from the F value of ANOVA. Mean comparison was achieved by Duncan's multiple range test.

\section{Results and Discussion}

\subsection{Weight Loss}

Weight loss during storage due to transpiration was observed for all treatments. Com- 
bination of $\mathrm{CO}_{2}$ and $\mathrm{MA}$ treatments showed significantly lower values than the control and $\mathrm{CO}_{2}$ treatment. Modified atmosphere such as box in bag, it maintained moisture and freshness. By Robinson et al., losses of $6 \%$ of the initial value of fresh weight of a soft fruit should be considered the limit for marketability [10]. In this study, after 14 days of storage, control had loss $2 \%$ and $\mathrm{CO}_{2}$ treatment had loss $3 \%$ due to stress of gas injection in acrylic chamber. However treated with combination of $\mathrm{CO}_{2}$ and MA was shown that loss of fresh weight was $1 \%$ in 14 days of storage at under $4^{\circ} \mathrm{C}$. Comparing all treatments, combination of $\mathrm{CO}_{2}$ and MA treatments had a significant effect on weight loss, presenting the lowest values (Figure 1).

\subsection{Firmness}

One of the main factors used to determine fruit quality and postharvest shelf life is the amount of loss of firmness during the storage of soft fruit such as strawberries [11]. By Manning [12], fruit softening is attributed to the degradation of cell wall components, mainly pectin, due to the action of specific enzymes such as polygalacturonase. The firmness of strawberries increased as the $30 \%$ concentration of carbon dioxide treatment within 3 hour. After vessel export at $1^{\circ} \mathrm{C}$, firmness was maintained higher than control in all storage condition (Figure 2). Although increases in fruit firmness were reported in other studies by the application of high level of carbon dioxide [5] [6], in addition to the firmness enhancement observed when strawberry fruit are held at low temperatures [13]. The firmness of strawberries after vessel export remained higher than harvest firmness values throughout the 15 day period of continuous cold storage at under $4^{\circ} \mathrm{C}$. By F.R. Harker et al., strawberries from all treatments softened rapidly and no residual effect of $\mathrm{CO}_{2}$-enhanced firming was detectable within 3 days at $20^{\circ} \mathrm{C}$ (data not shown) [6]. However, "Maehyang" strawberries treated with $\mathrm{CO}_{2}$ and $\mathrm{CO}_{2}+$ MA maintained firmness until 3 days at room temperature (over $26^{\circ} \mathrm{C}$ ), unlike that of

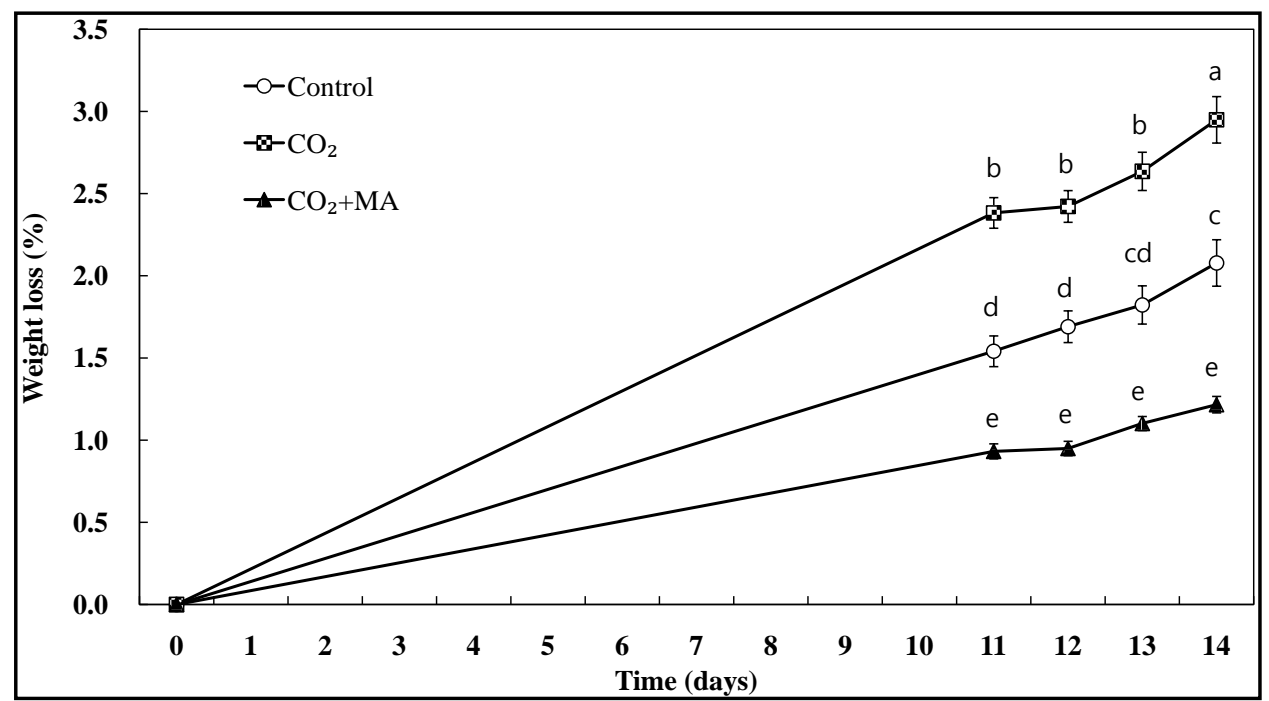

Figure 1. Changes in weight loss of "Maehyang" strawberries treated with $\mathrm{CO}_{2}$ alone or combination of $\mathrm{CO}_{2}$ and MA packaging after 10 days of transportation. Vertical lines represent S.E. 


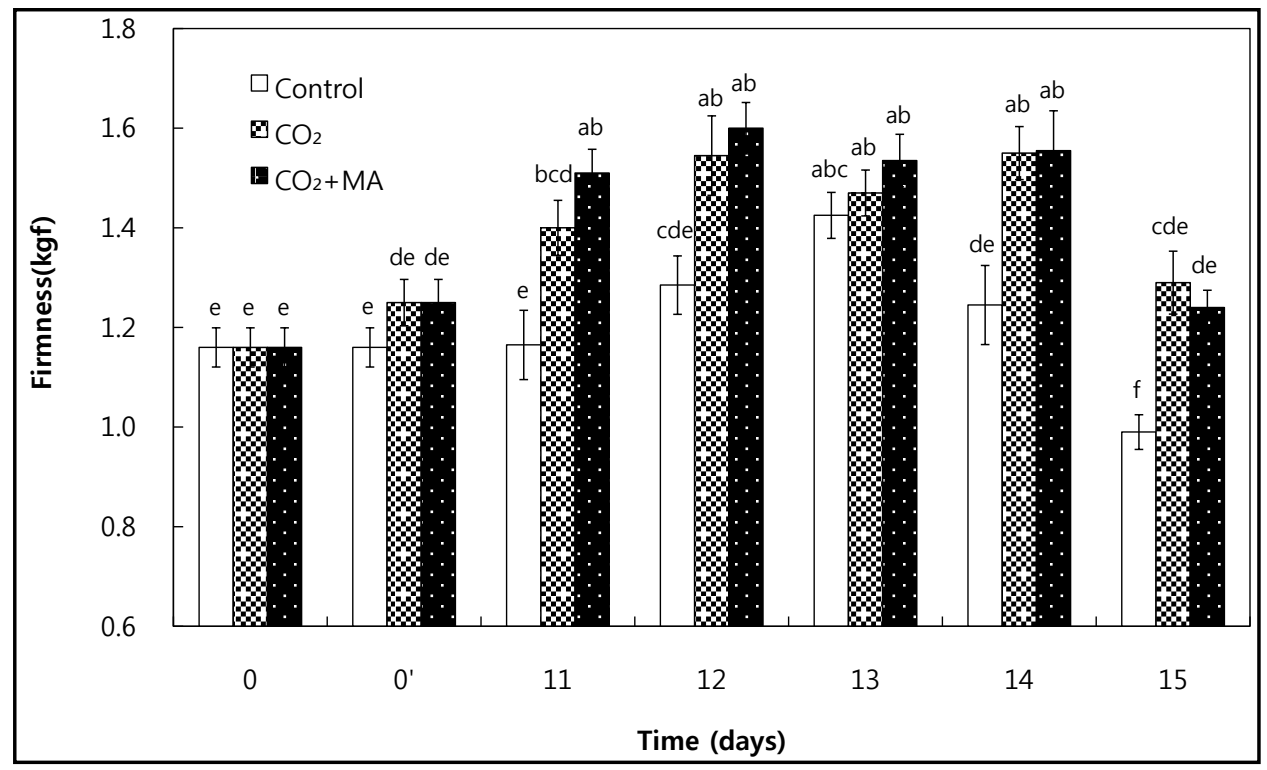

Figure 2. Changes in firmness of "Maehyang" strawberries treated with $\mathrm{CO}_{2}$ alone or combination of $\mathrm{CO}_{2}$ and MA packaging after 10 days of transportation during storage days at $4^{\circ} \mathrm{C} .0$ means at harvest before treatment. 0 ' means after treatment of $\mathrm{CO}_{2}$ for $3 \mathrm{hr}$ before storage. Vertical lines represent S.E. Different letters indicate significant differences at $\mathrm{p} \leq 0.05$.

untreated control.

\subsection{Total Soluble Solids}

Total soluble solids are a critical factor for determining fruit quality and consumer acceptability. Sugars are the main soluble metabolites, and include glucose, fructose and sucrose comprising $99 \%$ of total sugar content [14]. The TSS of cv. "Maehyang" strawberries at harvest was $10.88^{\circ}$ Brix and all treatments showed increases in the values during the storage time (Table 1). TSS was remained with low temperature storage, whereas TSS of "Maehyang" strawberries stored in retail market at $10^{\circ} \mathrm{C}-15^{\circ} \mathrm{C}$ were shown $9.72^{\circ}$ Brix at the end of marketing (after harvest 14 days).

\subsection{Sensory Quality}

Sensory quality is related to the characteristics of the food and how consumers perceive them [15]. With increasing storage time, deterioration starts with decay, fermentation and bruising [16]. Visual quality of "Maehyang" strawberries after vessel transportation was evaluated. Carbon dioxide alone and combination of $\mathrm{CO}_{2}$ and $\mathrm{MA}$ treatment were effective in delaying dark red coloration on fruit surface.

Softening index of "Maehyang" strawberries was the highest in the control group at 11 days of storage $\left(<4^{\circ} \mathrm{C}\right)$ (Figure 3$)$. After 15 days of storage $\left(<4^{\circ} \mathrm{C}\right)$, control showed higher score than those of $\mathrm{CO}_{2}$ and combined $\mathrm{CO}_{2}$ with MA treated strawberry. However, in low temperature storage under $4^{\circ} \mathrm{C}$, it restrained to occur softening on the surface of strawberry. Comparing all treatments, $\mathrm{CO}_{2}$ and combination of $\mathrm{CO}_{2}$ and $\mathrm{MA}$ treatments had a significant effect $(\mathrm{p}<0.05)$ on softening index, presenting lower 
Table 1. Changes in total soluble solids of "Maehyang" strawberry treated with carbon dioxide or MAP at different storage conditions after vessel export.

\begin{tabular}{ccccccccc}
\hline \multirow{2}{*}{ Storage condition } & Treatment & \multicolumn{7}{c}{ Time (days) } \\
\cline { 3 - 8 } & & 0 & $0^{\prime}$ & 11 & 12 & 13 & 14 \\
\hline & Control & $10.88 \pm 0.18$ & $10.88 \pm 0.18$ & $10.00 \pm 0.20$ & $11.18 \pm 0.37$ & $11.34 \pm 0.61$ & $13.76 \pm 0.15$ & $10.24 \pm 0.06$ \\
$4{ }^{\circ} \mathrm{C}$ & $\mathrm{CO}_{2}$ & $10.88 \pm 0.18$ & $12.44 \pm 0.35$ & $10.20 \pm 0.11$ & $11.58 \pm 0.57$ & $11.00 \pm 0.34$ & $11.04 \pm 0.28$ & $10.70 \pm 0.27$ \\
& $\mathrm{CO}_{2}+\mathrm{MA}$ & $10.88 \pm 0.18$ & $12.44 \pm 0.35$ & $11.00 \pm 0.36$ & $11.60 \pm 0.30$ & $11.48 \pm 0.20$ & $10.70 \pm 0.31$ & $10.18 \pm 0.20$ \\
$\begin{array}{c}\text { Retail marketing } \\
\left(10-15^{\circ} \mathrm{C}\right)\end{array}$ & $\mathrm{CO}_{2}$ & - & - & - & $9.88 \pm 0.20$ & $10.66 \pm 0.17$ & $9.72 \pm 0.20$ & - \\
\hline
\end{tabular}

0 means at harvest before treatment. 0 ' means after treatment of $\mathrm{CO}_{2}$ for $3 \mathrm{hr}$ before storage. Data are means \pm S.E.

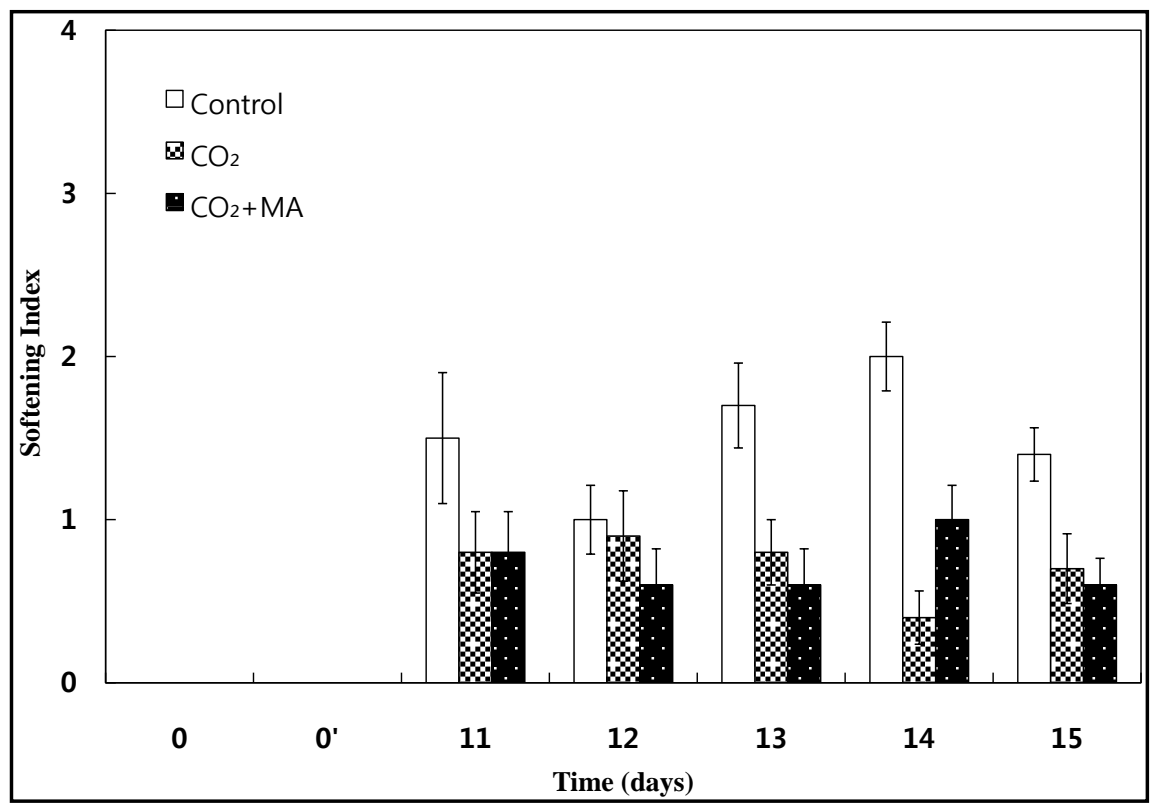

Figure 3. Softening index of "Maehyang" strawberries treated with $\mathrm{CO}_{2}$ alone or combination of $\mathrm{CO}_{2}$ and MA packaging after 10 days of transportation during storage days at $4^{\circ} \mathrm{C} .0$ means at harvest before treatment. 0 ' means after treatment of $\mathrm{CO}_{2}$ for $3 \mathrm{hr}$ before storage. Vertical lines represent S.E. Softening index was scored using five-point scale based on the degree of softening area of the fruit surface where $0=$ normal ( $0 \%$ surface softened), $1=$ trace (up to $10 \%$ surface softened), 2 = slight ( 10 to $25 \%$ surface softened), $3=$ moderate $(25 \%$ - $50 \%$ surface softened), and $4=$ severe $(>50 \%$ surface softened).

values than control.

Overall score of "Maehyang" strawberries decreased gradually in storage time in all treatments at room temperature after vessel export (Figure 4). Although samples of different treatments received marketable scores until 12 days of storage (cold storage following 10 days transportation). After 2 days at room temperature after cold storage following 10 days transportation, strawberries lost marketability in all the treatment representing severely softening. Non-treated control showed lower score than those of $\mathrm{CO}_{2}$ and $\mathrm{CO}_{2}+\mathrm{MA}$ treated strawberry.

Decay development is one of the main causes for postharvest losses of horticultural 


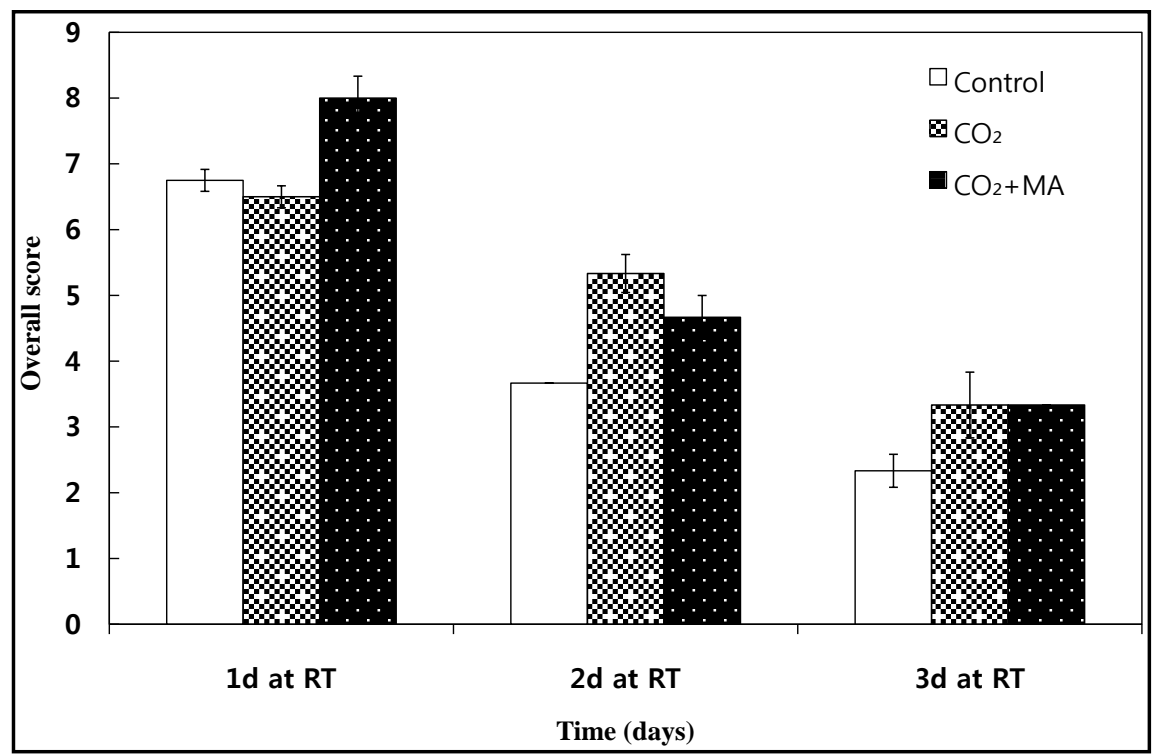

(a)

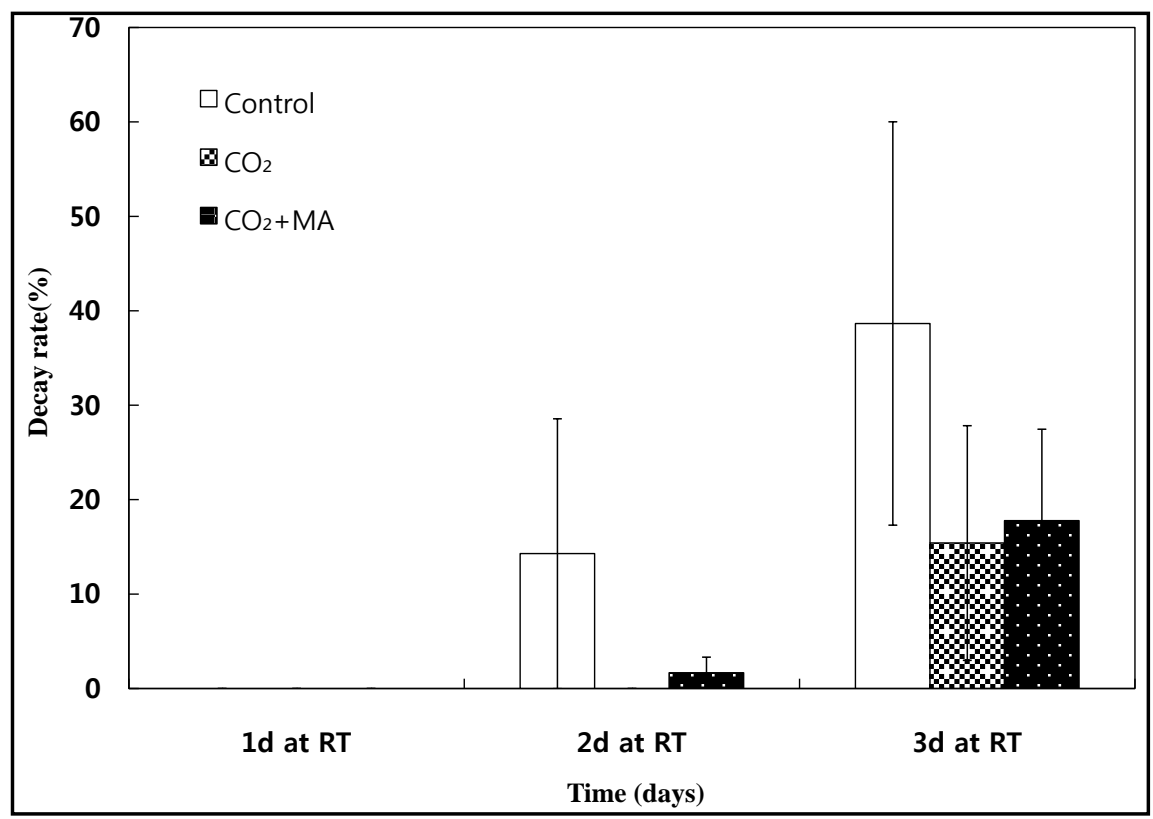

(b)

Figure 4. Overall quality score and decay rate of "Maehyang" strawberries treated with $\mathrm{CO}_{2}$ alone or combination of $\mathrm{CO}_{2}$ and MA packaging during storage period at room temperature $(1 \mathrm{~d}, 2 \mathrm{~d}$ and $3 \mathrm{~d}$ ) after cold storage following 10 day transportation was scored by three trained panelists using a 1 - 9 hedonic scale where $1=$ dislike extremely; 2 = dislike very much; $3=$ dislike moderately; $4=$ dislike slightly; $5=$ neither like nor dislike; $6=$ like slightly; $7=$ like moderately; $8=$ like very much; and $9=$ like extremely.

produce. In particularly, strawberries are highly susceptible to microbial infection and have a short shelf-life caused by Botrytis cinerea [17]. Fruit decay was not shown by cold temperature storage $\left(<4^{\circ} \mathrm{C}\right)$ for up to 15 days after harvest. However, the decay rate was the highest in the control group at 3 days room temperature storage cold sto- 
rage following 10 days transportation (Figure 4). High carbon dioxide levels may have inhibited decay by Nielsen and Leufven [18]. At the point of 2 days in room temperature, it occurred fungal decay on control and $\mathrm{CO}_{2}+\mathrm{MA}$. And after 3 days in room temperature, all treatments were shown that fungal decay on surface. In summary, worth notice is that we did not detect any decay at all when strawberry were sent immediately after vessel export and retail marketing, but only after storage at room temperature (simulation in wholesale market) high levels of fungal decay were shown after 2 days of storage on control and $\mathrm{CO}_{2}+\mathrm{MA}$, and after 3 days, all treatments were shown high percentage of fungal decay on fruit surface.

\section{Conclusion}

Maintaining the quality of highly perishable fruits, such as strawberries, associated with the cold, retail market, local chain systems after long term transporting, is a difficult subject. Atmosphere containing $30 \% \mathrm{CO}_{2}$ was effective in reducing decay rate and fruit softening and maintaining bright red color of "Mayhyang" strawberries during long term transportation and distribution. Samples treated with combination of $30 \% \mathrm{CO}_{2}$ and MA had higher overall score with low softening index and weight loss after 14 days of transportation and low temperature distribution. Thus, $\mathrm{CO}_{2}$ treatment alone or combination of $\mathrm{CO}_{2}$ and $\mathrm{MA}$ could be a practical postharvest technology to extend shelf-life of "Maehyang" strawberry. Therefore, "Maehyang" strawberry can be exported through vessel transportation.

\section{Acknowledgements}

This work was supported by Rep. of Korea-IPET project (315088-2, Development of shelf-life extension technology of fresh agricultural products for exports by sea transportation).

\section{References}

[1] Korea Rural Economic Institute (KREI) (2015) Agriculture in Korea 2015. 170.

[2] Chandra, D., Choi, A.J., Lee, J.S., Lee, J. and Kim, J.G. (2015) Changes in Physicochemical and Sensory Qualities of "Goha" Strawberries Treated with Different Conditions of Carbon Dioxide. Agricultural Sciences, 6, 325-334. https://doi.org/10.4236/as.2015.63033

[3] Park, J.E., Kim, H.M. and Hwang, S.J. (2012) Effect of Harvest Time, Precooling, and Storage Temperature for Keeping the Freshness of "Maehyang" Strawberry for Export. Journal of Bio-Environment Control, 21, 404-410. https://doi.org/10.12791/KSBEC.2012.21.4.404

[4] Eum, H.L., Bae, S.J., Hwang, D.K., Yeoung, Y.R. and Hong, S.J. (2014) Effects of Shipping Temperature and Precooling Treatment of Everbearing Strawberry Cultivars "Goha" and "Flamenco" Grown on Highland through Export Simulation. Korean Journal of Horticultural Science \& Technology, 32, 202-209.

[5] Lee, H.J., Kim, K.C., Piao, Y.L. and Hwang, Y.S. (2002) A Potential of Postharvest $\mathrm{CO}_{2}$ Treatment on the Market Quality of Strawberries during Simulated Export. Korean Journal of Agricultural Science, 29, 24-31.

[6] Harker, F.R., Elgar, H.J., Watkins, C.B., Jackson, P.J. and Hallett, I.C. (2000) Physical and Mechanical Changes in Strawberry Fruit after High Carbon Dioxide Treatments. Postharv- 
est Biology and Technology, 19, 139-146. https://doi.org/10.1016/S0925-5214(00)00090-9

[7] Kim, H.M. and Hwang, S.J. (2016) Effect of Chlorine Dioxide on Freshness of "Maehyang" Strawberries during Export. Korean Society for Horticultural Science, 34, 626-633.

[8] Giuggioli, N.R., Girgenti, V., Baudino, C. and Peano, C. (2015) Influence of Modified Atmosphere Packaging Storage on Postharvest Quality and Aroma Compounds of Strawberry Fruits in a Short Distribution Chain. Journal of Food Processing and Preservation, 39, 3154-3164. https://doi.org/10.1111/jfpp.12390

[9] AOAC (Association of Official Agricultural Chemist) (1990) Official Methods of Analysis. 12th Edition, AOAC International, Washington DC.

[10] Robinson, J.F., Browne, K.M. and Burton, W.G. (1975) Storage Characteristics of Some Vegetables and Soft Fruits. Annals of Applied Biology, 81, 399-408. https://doi.org/10.1111/j.1744-7348.1975.tb01656.x

[11] Tanada-Palmu, P.S. and Grosso, C.R. (2005) Effect of Edible Wheat Gluten-Based Films and Coatings on Refrigerated Strawberry (Fragaria ananassa) Quality. Postharvest Biology and Technology, 36, 199-208. https://doi.org/10.1016/j.postharvbio.2004.12.003

[12] Seymour, G.B., Taylor, J.E. and Tucker, G.A. (2012) Biochemistry of Fruit Ripening. Springer, Netherlands.

[13] Watkins, C.B., Manzano-Mendez, J.E., Nock, J.F., Zhang, J. and Maloney, K.E. (1999) Cultivar Variation in Response of Strawberry Fruit to High Carbon Dioxide Treatments. Journal of the Science of Food and Agriculture, 79, 886-890. https://doi.org/10.1002/(SICI)1097-0010(19990501)79:6<886::AID-JSFA303>3.0.CO;2-0

[14] Kafkas, E., Koşar, M., Paydaş, S., Kafkas, S. and Başer, K. (2007) Quality Characteristics of Strawberry Genotypes at Different Maturation Stages. Food Chemistry, 100, 1229-1236. https://doi.org/10.1016/j.foodchem.2005.12.005

[15] Costell, E. (2002) A Comparison of Sensory Methods in Quality Control. Food Quality and Preference, 13, 341-353. https://doi.org/10.1016/S0950-3293(02)00020-4

[16] Ares, G., Barrios, S., Lareo, C. and Lema, P. (2009) Development of a Sensory Quality Index for Strawberries Based on Correlation between Sensory Data and Consumer Perception. Postharvest Biology and Technology, 52, 97-102. https://doi.org/10.1016/j.postharvbio.2008.11.001

[17] Wszelaki, A. and Mitcham, E. (2003) Effect of Combinations of Hot Water Dips, Biological Control and Controlled Atmospheres for Control of Gray Mold on Harvested Strawberries. Postharvest Biology and Technology, 27, 255-264. https://doi.org/10.1016/S0925-5214(02)00095-9

[18] Nielsen, T. and Leufven, A. (2008) The Effect of Modified Atmosphere Packaging on the Quality of Honeoye and Korona Strawberries. Food Chemistry, 107, 1053-1063. https://doi.org/10.1016/j.foodchem.2007.09.025 
Submit or recommend next manuscript to SCIRP and we will provide best service for you:

Accepting pre-submission inquiries through Email, Facebook, LinkedIn, Twitter, etc. A wide selection of journals (inclusive of 9 subjects, more than 200 journals)

Providing 24-hour high-quality service

User-friendly online submission system

Fair and swift peer-review system

Efficient typesetting and proofreading procedure

Display of the result of downloads and visits, as well as the number of cited articles

Maximum dissemination of your research work

Submit your manuscript at: http://papersubmission.scirp.org/

Or contact as@scirp.org 